\title{
Pirarucu By-Product Acid Silage Meal in Diets for Commercial Laying Hens
}

\section{-Author(s)}

\section{Batalha OS \\ Alfaia SS" \\ Cruz FGG III \\ Jesus RS" \\ Rufino JPFIN \\ Silva AFIV}

Graduate Program of Agriculture in Humid Tropics, National Institute of Amazonian Researches, Manaus, AM, Brazil.

" National Institute of Amazonian Researches, Manaus, AM, Brazil.

III Department of Animal and Plant Production, College of Agrarian Sciences, Federal University of Amazonas, Manaus, Amazonas, Brazil.

Iv Graduate Program of Animal Science, College of Agrarian Sciences, Federal University of Amazonas, Manaus, Amazonas, Brazil.

\section{- Mail Address}

Corresponding author e-mail address Oscarina de Souza Batalha

Setor de Avicultura, Faculdade de Ciências Agrárias, Setor Sul do Campus Universitário da Universidade Federal do Amazonas, Av. General Rodrigo Octávio Jordão Ramos, 6200, Bairro Coroado I, Manaus, AM, Brasil - 69077-000.

Tel: $\quad$ (92) 991221957

Email: oscarinabatalha@gmail.com

\section{aKeywords}

Alternative food, egg quality, fish byproduct, flavor, performance.

\section{ABSTRACT}

This study aimed to evaluate the inclusion of pirarucu by-product acid silage meal in diets for laying hens on performance and egg quality. One hundred sixty eight Hissex White laying hens 73-wk-old were distributed in completely randomized design with seven treatments $(0,0.5,1.0,1.5,2.0,2.5$ and $3.0 \%)$ and four replicates of six birds each. The experiment lasted 84 days divided into four periods of 21 days. Estimates of pirarucu by-product meal levels were determined by polynomial regression. Differences $(p<0.05)$ were observed in all variables of performance, in egg weight, yolk height and yolk pigmentation, with pirarucu by-product meal inclusion in diets showed better results than control diet. The pirarucu by-product acid silage meal can be used as alternative food in diets for commercial laying hens. Up to the $2.5 \%$ inclusion level there wasn't negative effect in performance and egg quality.

\section{INTRODUCTION}

Currently, poultry production (egg and meat) have featured in the international_economic activity, being uniformed and without geographical frontier. However, one of the obstacles faced by this sector in some Brazilian regions is a great need of corn and soybean meal, the main ingredients used in the poultry feed production, which usually raises the production cost.

In this context, researches with alternative ingredients show potential for the inclusion or substitution of the conventional ingredients in poultry feed, aimed to lower the feed costs that represents $70 \%$ of production costs (Cruz et al., 2016). Therefore, the by-products used for poultry feed can have lower investments, mainly because of the bypodructs being low cost ingredients, and that offer diets with higher nutritive composition (Enke et al., 2010).

A product that's currently studied is the fish by-product in silage form, with its production offering great economic advantages, requiring a simple technology and independent of production scale (Hisano et al., 2012). Furthermore, it has a low cost transformation of waste materials in products with high nutritional quality and minimizes problems with environmental pollution.

Silage may be defined as a pasty product with high nutritional value resulting from the conservation of the whole fish or its residual parts. It consists in acidifying the $\mathrm{pH}$ through the addition of organic acids (Borghesi et al., 2008) that benefit the autolytic enzymatic reactions present in the muscle, raising the levels of oligopeptides and free amino acids in the final product (Honorato et al., 2012).

Thus, this study aimed to evaluate the inclusion of pirarucu byproduct acid silage meal in diets for laying hens on performance and egg quality. 


\section{MATERIAL AND METHODS}

The experiment was developed in the Poultry Sector of the Department of Animal and Plant Production (DPAV), College of Agrarian Sciences (FCA), Federal University of Amazonas (UFAM), located in the Southern Sector of the University Campus, Manaus, state of Amazonas, Brazil.

The experimental procedures were conducted in accordance with the ethical principles for animal experimentation adopted by the Brazilian College of Animal Experimentation (COBEA) and the experimental procedures were approved by the local Committee for Ethical Animal Use (CEUA - protocol n. 040/2015) of the Federal University of Amazonas, Manaus, Amazonas, Brazil.

The experimental period lasted 84 days, divided into four periods of 21 days. Before the start of the experiment, the birds were subjected to an adaptation period of seven days regarding the feed and facilities.

The experimental aviary used had dimensions of $17.0 \mathrm{~m}$ in length and $3.5 \mathrm{~m}$ in width, containing galvanized wire cages, trough feeders and nipple drinkers. 168 Hissex White hens with 73 weeks of age were used. The birds were weighed at the beginning of the experiment in order to standardize the experimental plots, presenting a mean weight of $1.53 \pm 0.0025 \mathrm{~kg}$. Egg collection was performed two times a day ( 8 a.m. and 3 p.m.), recording each daily occurrence (mortality, number of eggs, among other information). The temperature and relative humidity were recorded two times a day (9:00 a.m. and 3:00 p.m.) from a digital term hygrometer positioned above the bird's cage in the aviary, with mean results of $28.65 \pm 0.01{ }^{\circ} \mathrm{C}$ and $73.45 \%$, respectively.

The experimental design was completely randomized consisting of seven treatments corresponding to the inclusion levels of pirarucu byproduct acid silage meal $(0,0.5,1.0,1.5,2.0,2.5$ and $3.0 \%$ ) in the diet, with four replicates of six birds each. Throughout the experimental period 16 hours of light/day (12 natural hours +4 artificial hours) were provided to the birds.

The acid silage was produced and dehydrated in the Fish Technology Laboratory of National Researches Institute of the Amazon (INPA). The pirarucu residues (ribs and vestebras) were crushed in an electric crusher machine. Formic and propionic acids were mixed in 1: 1 proportion of $3 \%$ acid solution volume of total weight, with constant homogenization to acidify the medium, lower the $\mathrm{pH}$ to inhibit the proliferation of microorganisms and to promote protein hydrolysis according to Borghesi et al. (2008).

The recipients were kept at ambient temperature for three days, and scrambled each 24 hours to promote the incorporation of the acids into the ensiled mass. In the end of 72 hours, to reduce humidity, the ensiled material was dried in laboratory stove $\left(65^{\circ} \mathrm{C}\right.$ for 72 hours).

The chemical composition was determined in the Laboratory of Chemistry and Physical- Chemistry of Food of INPA, with methodology by Silva and Queiroz (2002). The minerals were digested in nitric-perchloric extract and the concentrations quantified by atomic absorption spectrophotometer (Ca) and colorimetry (P) according to Sarruge and Haag (1974) in the Thematic Laboratory of Soils and Plants Chemistry of INPA. After the determination of the chemical composition (Table 1), the product was packed and sent to the Poultry Sector of FCA/UFAM, being crushed to obtain the pirarucu by-product acid silage meal.

Table 1 - Chemical composition of pirarucu by-product acid silage meal.

\begin{tabular}{lc}
\hline Chemical composition & Pirarucu by-product acid silage meal* \\
\hline Dry matter, \% & $84.16 \pm 0.08$ \\
\hline Crude protein, \% & $40.05 \pm 0.83$ \\
\hline Ether extract, \% & $26.81 \pm 0.13$ \\
Mineral matter, \% & $9.31 \pm 0.22$ \\
Total carbohydrates, \% & $7.99 \pm 0.74$ \\
Calcium, g/kg & $65.16 \pm 1.49$ \\
Phosphorus, g/kg & $22.90 \pm 2.30$ \\
Metabolizable energy, kcal/kg & $3,253.01^{* *}$ \\
\hline *Averages withdrawal of three replicates \pm standard deviation. \\
**Determined by the method for apparent metabolizable energy calculation according \\
to Rostagno et al. (2011).
\end{tabular}

The experimental diets were formulated according to the nutritional requirements of laying hens according to Rostagno et al. (2011), also using the composition obtained for pirarucu by-product acid silage meal (Table 2).

For animal performance, we evaluated in each period of feed intake ( $\mathrm{g} / \mathrm{bird} /$ day), the egg production (\%), egg mass ( $\mathrm{g}$ ), feed conversion ( $\mathrm{kg}$ feed per $\mathrm{kg}$ egg produced - $\mathrm{kg} / \mathrm{kg}$ ) and feed conversion ( $\mathrm{kg}$ feed per dozen eggs produced $-\mathrm{kg} / \mathrm{dz}$ ). In the last two days of each period, four eggs from each plot were taken at random to evaluate egg quality, in which we analyzed egg weight (g), albumen weight (\%), yolk weight (\%), albumen height $(\mathrm{mm})$, yolk height $(\mathrm{mm})$, shell thickness $(\mu \mathrm{m})$ and specific gravity $\left(\mathrm{g} / \mathrm{cm}^{3}\right)$. Before evaluation, the eggs were stored for one hour in order to equalize the temperature to room temperature. 
Table 2 - Diets composition containing pirarucu by-product acid silage meal (PBASM).

\begin{tabular}{|c|c|c|c|c|c|c|c|}
\hline \multirow{2}{*}{ Ingredients } & \multicolumn{7}{|c|}{ Pirarucu by-product acid silage meal levels } \\
\hline & $0.0 \%$ & $0.5 \%$ & $1.0 \%$ & $1.5 \%$ & $2.0 \%$ & $2.5 \%$ & $3.0 \%$ \\
\hline Corn $(7.88 \%)$ & 62.255 & 62.170 & 62.087 & 62.005 & 61.922 & 61.839 & 61.756 \\
\hline Soybean meal (46\%) & 25.871 & 25.527 & 25.173 & 24.819 & 24.466 & 24.112 & 23.758 \\
\hline PBASM & 0.000 & 0.500 & 1.000 & 1.500 & 2.000 & 2.500 & 3.000 \\
\hline Limestone & 9.239 & 9.167 & 9.095 & 9.023 & 8.950 & 8.878 & 8.806 \\
\hline Dicalcium phosphate & 1.693 & 1.696 & 1.700 & 1.704 & 1.708 & 1.712 & 1.716 \\
\hline Vit. min. supplement ${ }^{1}$ & 0.500 & 0.500 & 0.500 & 0.500 & 0.500 & 0.500 & 0.500 \\
\hline DL-methionine (99\%) & 0.092 & 0.089 & 0.094 & 0.099 & 0.104 & 0.109 & 0.113 \\
\hline Salt & 0.350 & 0.350 & 0.350 & 0.350 & 0.350 & 0.350 & 0.350 \\
\hline Total & 100.00 & 100.00 & 100.00 & 100.00 & 100.00 & 100.00 & 100.00 \\
\hline Nutrient & \multicolumn{7}{|c|}{ Nutritional levels } \\
\hline M.E., $\mathrm{kcal}^{-1} / \mathrm{kg}$ & $2,692.6$ & $2,686.8$ & $2,671.3$ & $2,660.8$ & $2,650.2$ & $2,639.7$ & $2,629.2$ \\
\hline Crude protein, \% & 17.000 & 17.000 & 17.000 & 17.000 & 17.000 & 17.000 & 17.000 \\
\hline Methionine + Cystine, \% & 0.627 & 0.620 & 0.620 & 0.620 & 0.620 & 0.620 & 0.620 \\
\hline Methionine, \% & 0.360 & 0.361 & 0.369 & 0.378 & 0.387 & 0.395 & 0.404 \\
\hline Calcium, \% & 4.000 & 4.000 & 4.000 & 4.000 & 4.000 & 4.000 & 4.000 \\
\hline Available phosphorus, \% & 0.400 & 0.400 & 0.400 & 0.400 & 0.400 & 0.400 & 0.400 \\
\hline Sodium, \% & 0.156 & 0.156 & 0.156 & 0.156 & 0.156 & 0.156 & 0.156 \\
\hline
\end{tabular}

'Guaranteedlevels per kilogramoftheproduct: Vitamin A 2,000,000 IU, Vitamin D3 400,000 IU, Vitamin E 2,400 mg, Vitamin K3 400 mg, Vitamin B1 100 mg, Vitamin B2 760 mg, Vitamin B6 100 mg, Vitamin B12 2,400 mcg, Niacin 5,000 mg, CalciumPantothenate 2,000 mg, Folicacid 50 mg, Coccidiostat 12,000 mg, Choline 50,000 mg, Copper 1,200 mg, Iron 6,000 mg, Manganese 14,000 mg, Zinc 10,000 mg, lodine $100 \mathrm{mg}$. Selenium $40 \mathrm{mg}$. Vehicle q.s.p. 1,000 g.

The eggs were weighed on an electronic scale to the nearest $0.01 \mathrm{~g}$. The egg mass was obtained by calculating the quotient between egg weight and egg production multiplied by 100. The whole eggs, immediately after weighing, were placed in wire baskets and immersed in plastic buckets containing different levels of sodium chloride $(\mathrm{NaCl})$, from the lowest to the highest concentration, with density variations from 1.075 to $1.100 \mathrm{~g} / \mathrm{cm}^{3}$, with 0.005 -interval. The eggs were removed as they floated to the surface and their respective values were recorded.

For the analysis of the albumen and yolk weight, a manual separator of albumen and yolk was used. The albumen and the yolk were placed in plastic cups, tared-weight in an analytical balance, and weighed. To calculate the albumen and yolk weight, they were placed on a flat glass plate to determine their respective values. The criterion for measuring albumen and yolk height is to take measure at the medial region between the outer border of the albumen and the yolk. For the measurement of the height, an electronic caliper was used; the values are expressed in millimeters.

The egg shell weight was obtained after they were washed, dried at room temperature for 48 hours and then weighed in grams. Dry shells were used to determine the shell thickness, which were measured using a micrometer. The readings were performed in three regions of the shell: basal, meridional and apical, and the values were recorded. From the values obtained in the three regions, the average of the eggshell thickness, in micrometer, was calculated. The egg yolk color was evaluated with the Roche colorimetric fan with a score of 1 to 15 . Haugh unit was performed using the egg weight and albumen height values and the results obtained by the formula $\mathrm{UH}=100 \times \log (\mathrm{H}$ $\left.+7.57-1.7 \times W^{0.37}\right)$, where $H=$ albumen height $(\mathrm{mm})$; and $\mathrm{W}=$ egg weight $(\mathrm{g})$.

Data collected were tested by analysis of variance with the GLM procedure of the Statistical Analysis System-SAS (2008) software and subjected to the polynomial regression analysis at the $5 \%$ level of significance.

\section{RESULTS AND DISCUSSION}

Differences $(p<0.05)$ were observed in feed intake, egg production, feed conversion $(\mathrm{kg} / \mathrm{kg}$ and $\mathrm{kg} / \mathrm{dz}$ ) and egg mass results of laying hens fed with diets containing pirarucu by-product acid silage meal (Table 3).

Feed intake showed quadratic effect $\left(Y=-0.3122 x^{2}\right.$ $\left.+0.4704 x+110.77, R^{2}=0.85\right)$ with great intake of $111.14 \mathrm{~g} / \mathrm{bird} /$ day in inclusion level of $0.75 \%$ of pirarucu by-product acid silage meal. These results desagreed of Enke et al. (2010) that working with fish by-product acid silage meal, added to defatted rice meal in the diets of Japanese quail (Coturnixcoturnix japonica) didn't observe differences among levels tested.

The low intake observed in the higher levels can be related to the reduction of the palatability from the growing inclusion of pirarucu by-product acid silage 
Table 3 - Feed intake (FI), egg production (EP), egg mass (EM) and feed conversion ( $F C, \mathrm{~kg} / \mathrm{kg} \mathrm{e} \mathrm{kg} / \mathrm{dz}$ ) of commercial laying hens fed diets containing pirarucu by-product acid silage meal.

\begin{tabular}{|c|c|c|c|c|c|c|c|c|c|c|}
\hline \multirow{2}{*}{ Variables } & \multicolumn{7}{|c|}{ Pirarucu by-product acid silage meal levels (\%) } & \multirow{2}{*}{ P Valor } & \multirow[b]{2}{*}{ Effect } & \multirow{2}{*}{$\begin{array}{c}C V \\
\%\end{array}$} \\
\hline & 0.0 & 0.5 & 1.0 & 1.5 & 2.0 & 2.5 & 3.0 & & & \\
\hline Fl, g/bird/day & 110.42 & 110.84 & 110.81 & 110.52 & 109.24 & 109.89 & 104.78 & 0.01 & Q & 0.46 \\
\hline$E P, \%$ & 89.98 & 93.90 & 88.09 & 83.93 & 89.53 & 89.38 & 66.86 & 0.01 & Q & 5.14 \\
\hline EM, g & 70.50 & 69.45 & 68.98 & 68.34 & 68.57 & 67.66 & 52.42 & 0.01 & Q & 4.43 \\
\hline $\mathrm{FC}, \mathrm{kg} / \mathrm{kg}$ & 1.56 & 1.60 & 1.62 & 1.63 & 1.59 & 1.58 & 2.01 & 0.01 & Q & 5.06 \\
\hline $\mathrm{FC}, \mathrm{kg} / \mathrm{dz}$ & 2.92 & 2.81 & 3.00 & 3.14 & 2.91 & 2.93 & 3.74 & 0.01 & $\mathrm{Q}$ & 5.63 \\
\hline
\end{tabular}

CV - Coefficient of variation. P Valor - Coefficient of Probability. Q - Quadratic effect.

meal in diets for laying hens and the specific composition of the fish species used. Similar results were obtained by Al-Marzooqi et al. (2010), that observed a decrease in intake from inclusion of sardine acid silage in diets for broilers, and Rahman \& Koh (2015), who also observed a decrease in feed intake of broilers fed diets with shrimp meal treated with formic acid.

Another factor for the decrease in feed intake of laying hens fed with great inclusion levels can be related to the energy content in the by-product used, once excess fat in the diet leads to satiety by the animal and causes changes in the feed intake because it's an essential control factor.

According Carioca et al. (2010), the more energy in food, less will be consumed. And this decrease in intake, physiologically, can be caused by the presence of lipid in the duodenum that stimulates the release of hormone cholecystokinin (CCK), that causes the enterogastric reflex, decreasing passage rate through the digestive system, with consequent absorption of nutrients (Brunelli et al., 2010; Pinheiro et al., 2012; Torres and Drehe, 2015). However, the modern laying hens have the ability to adjust feed intake from food energy content (Gunawardana et al., 2008; Ribeiro et al., 2014).

It's important to mention that studies carried out to evaluate broilers fed diets with fish residue silage have obtained different results, such as increase in feed intake of $90-128 \mathrm{~g} / \mathrm{bird}$ at the $15 \%$ of salmon acid silage inclusion (Valenzuela et al., 2015) and inclusion of 30\% of this by-product in diets of broilers don't influenced the feed intake (Ramirez-Ramirez et al., 2016).

The egg production showed quadratic effects from increased levels of pirarucu by-product acid silage meal $\left(Y=-1.0045 x^{2}+1.5881 x+93.892, R^{2}=0.72\right)$ with great production index $(94.51 \%)$ obtained with the inclusion level of $0.79 \%$. Consequently, when evaluating the egg mass, a quadratic effect was observed $\left(Y=-0.7946 x^{2}+0.7612 x+70.611, R^{2}=\right.$ $0.74)$ obtaining great result $(70.79 \mathrm{~g})$ in $0.47 \%$ of pirarucu by-product acid silage meal inclusion.
From these results, it was also observed that hens fed lower levels of this by-product showed better production and egg mass, whereas the increase of levels caused a physiological break point with replied on feed intake and, consequently, other performance variables.

According Pérez-Bonilla et al. (2012), changes in diets composition, such as the inclusion of products of animal origin, may cause an increase in body weight gain and decrease in performance of hens.

The feed conversion $(\mathrm{kg} / \mathrm{kg})$ showed quadratic effect $\left(Y=0.0203 x^{2}-0.0753 x+1.7239, R^{2}=0.71\right)$ with great conversion of $1.65 \mathrm{~kg} / \mathrm{kg}$ in $1.85 \%$ of inclusion, corroborated with results of feed conversion $(\mathrm{kg} / \mathrm{dz})$, that also showed quadratic effect $(Y=$ $\left.0.0361 x^{2}-0.1156 x+3.3289, R^{2}=0.78\right)$, with better conversion $(3.23 \mathrm{~kg} / \mathrm{dz})$ in inclusion level of $1.60 \%$. The feed conversions $(\mathrm{kg} / \mathrm{kg}$ and $\mathrm{kg} / \mathrm{dz}$ ) showed worst results from inclusion of highest pirarucu by-product acid silage meal levels, with a direct relationship with feed intake results. These results agree with Hanna et al. (2013) that studying increasing levels of copaiba oil as an energetic alternative food in diets for laying hens observed a decrease on performance in most high inclusion levels.

In egg weight (Table 4) a quadratic effect was observed $\left(Y=-0.5817 x^{2}+3.1783 x+60.226, R^{2}=\right.$ 0.78 ) with better egg weight $(64.56 \mathrm{~g})$ in $2.73 \%$ of pirarucu by-product acid silage meal inclusion in the diets. These results corroborated with Jonsson et al. (2011), who also observed differences to hens fed diets with $3.5 \%$ of clam meal.

Hens fed the highest levels of pirarucu by-product acid silage meal showed lighter eggs. Wall et al. (2010), affirms that changes in egg weight from diets containing increase levels of fish meal or fish oil are possibly associated with dietary omega-3 and changes caused in birds lipid metabolism.

In this context, the yolk height showed quadratic effect $\left(Y=-0.1306 x^{2}+0.6193 x+19.178, R^{2}=0.77\right)$ with better results $(19.91 \mathrm{~mm})$ in inclusion level of 
Table 4 - Egg weight (EW), albumen percentage (PERA), yolk percentage (PERY), shell percentage (PERS), albumen height $(\mathrm{AH})$, yolk height $(\mathrm{YH})$, shell thickness (ST), specific gravity (SG), Haugh unit (HU) and yolk pigmentation (YP) of eggs from commercial laying hens fed diets containing pirarucu by-product acid silage meal.

\begin{tabular}{|c|c|c|c|c|c|c|c|c|c|c|}
\hline \multirow{2}{*}{ Variables } & \multicolumn{7}{|c|}{ Pirarucu by-product acid silage meal levels (\%) } & \multirow[b]{2}{*}{$p$ Valor } & \multirow{2}{*}{ Effect } & \multirow{2}{*}{$C V, \%$} \\
\hline & 0.0 & 0.5 & 1.0 & 1.5 & 2.0 & 2.5 & 3.0 & & & \\
\hline EW, g & 63.85 & 62.23 & 61.67 & 61.21 & 62.77 & 63.19 & 50.01 & 0.01 & Q & 4.31 \\
\hline PERA, \% & 54.59 & 54.66 & 56.72 & 53.69 & 53.63 & 56.02 & 52.91 & 0.07 & ns & 3.28 \\
\hline PERY, \% & 26.42 & 27.05 & 27.18 & 27.88 & 27.89 & 27.87 & 26.85 & 0.31 & ns & 3.80 \\
\hline PERS, \% & 9.43 & 9.55 & 9.60 & 10.01 & 9.20 & 9.39 & 9.73 & 0.09 & ns & 3.77 \\
\hline $\mathrm{AH}, \mathrm{mm}$ & 7.73 & 7.21 & 7.68 & 7.86 & 7.50 & 7.77 & 7.49 & 0.29 & ns & 5.04 \\
\hline $\mathrm{YH}, \mathrm{mm}$ & 17.72 & 17.43 & 18.06 & 18.77 & 19.42 & 18.67 & 17.59 & 0.05 & $\mathrm{Q}$ & 5.15 \\
\hline $\mathrm{ST}, \mu \mathrm{m}$ & 33.77 & 35.90 & 35.17 & 35.35 & 35.09 & 35.02 & 36.26 & 0.32 & ns & 4.00 \\
\hline $\mathrm{SG}, \mathrm{g} / \mathrm{mL}$ & 1084.92 & 1102.26 & 1084.22 & 1087.11 & 1083.05 & 1083.91 & 1133.54 & 0.43 & ns & 3.34 \\
\hline $\mathrm{HU}$ & 85.55 & 84.15 & 86.90 & 87.63 & 85.49 & 86.92 & 85.87 & 0.43 & ns & 2.68 \\
\hline YP & 4.79 & 5.23 & 5.17 & 5.36 & 5.29 & 5.26 & 4.73 & 0.01 & Q & 5.04 \\
\hline
\end{tabular}

CV - Coefficient of variation. P Valor - Coefficient of Probability. Q - Quadratic effect. ns - non significant.

2.37\%. According studies testing inclusion levels of fish meal and oil in diets for hens and quails performed by Al-Daraji et al. (2011), Alemayehu et al. (2015) and Amao et al. (2010), observed significant increase in yolk height. Cedro et al. (2010) and Sherr et al. (2014) affirm that these results can have relationship to omega-3 and omega- 6 content and other lipid components present in fish residues, that through the process of acid ensilage (Costa et al., 2012) can contribute to the increase in yolk height.

A quadratic effect was observed in yolk pigmentation $\left(Y=-0.0618 x^{2}+0.194 x+5.3817 R^{2}=0.87\right)$, showing better pigmentation (5.53) in inclusion level of $1.56 \%$. Wall et al. (2010), observed that hens fed diets with $3.5 \%$ of clam meal inclusion showed significant influence on yolk pigmentation. These results may be attributed to pigments called carotenoids present naturally in corn (Brunelli et al., 2012) that associated with lipid profile present in pirarucu by-product acid silage meal can contribute to the increase the yolk pigmentation.

According to Lopes et al. (2011) the carotenoids are liposoluble substances transferred by the same mechanisms from lipids to ovarian follicles, where stored as fats or lipoproteins in yolks. But, the yolk pigmentation will depend on the type of ingredients used in the feed composition and the pigments necessary for color development. Saleh (2013) observed that fish oil inclusion contributed to the darkening of yolk at $5 \%$ in diets for hens.

\section{CONCLUSIONS}

The pirarucu by-product acid silage meal can be used as alternative food in diets for commercial laying hens. Up to $2.5 \%$ inclusion levels there wasn't a negative effect in performance and egg quality.

\section{REFERENCES}

Al-Daraji HJ, Al-Mashadani HA, Mirza HA, Al-Hayani WK, Al-Hassani AS. Influence of source of oil added to diet on egg quality traits of laying quail. International Journal of Poultry Science 2011;10(2):130-136.

Alemayehu Y, Urge M, Getu A. Effects of levels of inclusion of locally processed fish waste meal in the diets of white leghorn layers on performance parameters, hatchability, economics, egg production and egg quality. Iranian Journal of Applied Animal Science 2015;5(3):689698.

Al-Marzooqi W, Al-Farsi MA, Kadim IT, Mahgoub O, Goddard JS. The effect of feeding different levels of sardine fish silage on broiler performance, meat quality and sensory characteristics under closed and open-sided. Asian-Australasian Journal Animal Sciences 2010;23(12):1614-1625.

Amao OA, Oladunjoye 1O, Togun VA, Olubajo K, Oyaniyi O. Effect of westwood (Cirinaforda) larva meal on the laying performance and egg characteristics of layng hen in a tropical environment. International Journal of Poultry Science 2010;9(5):450-454.

Borghesi R, Portz L, Oetterer M, Cyrino JEP. Apparent digestibility coeficiente of protein and amino acids of acid, biological and enzymatic silage for Nile tilapia (Oreochromisniloticus|). Aquaculture Nutrition 2008; 14(3):242-248.

Brunelli SR, Pinheiro JW, Fonseca NAN, Oba A, Silva CA. Farelo de gérmen de milho desengordurado na dieta de poedeiras comerciais de 28 a 44 semanas de idade. Revista Brasileira de Zootecnia 2010;39(5):10681073.

Brunelli SR, Pinheiro JW, Fonseca NAN, Silva CA. Efeito de diferentes níveis de farelo de gérmen de milho desengordurado em dietas suplementadas com fitase para poedeiras comerciais. Ciências Agrárias 2012;33(5):1991-2000.

Carioca ST, Cruz FGG, Matos PGJ, Maquine LC, Chagas EO, Oliveira SC, et al. Influência dos níveis energéticos e proteicos em rações de poedeiras leves em Manaus. Archivos da Zootecnia 2010;59(227):455-458.

Cedro TMM, Calixto LFL, Gaspar A, Hora AS. Teores de ácidos graxos em ovos comerciais convencionais e modificados com ômega-3. Revista Brasileira de Zootecnia 2010;39(8):1733-1739. 
Batalha OS, Alfaia SS, Cruz FGG, Jesus RS, Rufino JPF, Silva AF

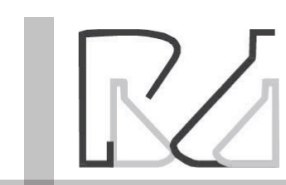

Pirarucu By-Product Acid Silage Meal in Diets for Commercial Laying Hens
Costa CN, Silva JR, Melo FVT, Hisano H, Druzian JI, Portz L. Incorporação de ômega-3 no tecido muscular da tilápia do Nilo alimentada com dietas contendo silagem de cabeça de camarão. Ciência Rural 2012;42(1):172-177.

Cruz FGG, Rufino JPF, Melo RD, Feijó JC, Damasceno JL, Costa APGC. Perfil socioeconômico da avicultura no setor primário do estado do Amazonas, Brasil. Revista em Agronegócios e Meio Ambiente 2016;9(2):371-391.

Diarra SS, Kant R, Tanhimana J, Lela P. Utilization of Giant African snail (Achatinafulica) meal as protein source for laying hens. Journal of Agriculture and Rural Development in the Tropics and Subtropics 2015;116(1):85-90.

Dutcosky SD. Análise sensorial de alimentos. Curitiba: Champagnat; 2007.

Enke DBS, Tabeleão V, Rocha CB, Rutz F, Soares LAS. Efeito da inclusão de farinha de silagem de pescado adicionada de farelo de arroz desengordurado na dieta de codornas japonesas (Coturnix coturnix japonica). Revista Brasileira de Higiene e Sanidade Animal 2010;4(2):114.

Gunawardana P, Roland DA, Bryant MM. Effect of energy and protein on performance, egg components, egg solids, egg quality, and profits in molted Hy-Line W-36 hens. The Journal of Applied Poultry Research 2008;17(4):432-439.

Hanna ACS, Cruz FGG, Rufino JPF, Tanaka ES, Chagas EO, Melo JBS. Bioefficacy of the copaiba Oil (Copaifera sp.) in diets of laying hens in the second production cycle in humid tropical climate. International Journal of Poultry Science 2013;2(11):647-652.

Hisano $\mathrm{H}$, Ishikawa MM, Portz L. Produção de silagem ácida a partir de vísceras de surubim (Pseudoplatystoma sp.) e avaliação da digestibilidade para tilápia-do-nilo. Revista Brasileira de Saúde e Produção Animal 2012;13(3):872-879.

Honorato C, Frizzas GO, Carneiro DJ. Digestibilidade da silagem de peixe com diferentes tempos de armazenamento para alimentação do pacu (piaractusmesopotamicus). Ensaios e Ciência: Ciências Biológicas, Agrárias e da Saúde 2012;16(5):85-95.

Jonsson L, Wall H, Tauson R. Production and egg quality in layers fed organic diets with mussel meal. Animal 2011;5(3):387-393.

Lopes IRV, Freitas ER, Lima JR, Neto JLV, Bezerra RM, Lima RC. Desempenho e qualidade dos ovos de poedeiras comerciais alimentadas com rações contendo farelo de coco tratado ou não com antioxidante. Revista Brasileira de Zootecnia 2011;40(11):2431-2438

Pérez-Bonilla A, Novoa S, García J, Mohiti-Asli M, Frikha M, Mateos GG. Effects of energy concentration of the diet on productive performance and egg quality of brown egg-laying hens differing in initial body weight. Poultry Science 2012;91(12):3156-3166.
Pinheiro JW, Fonseca NAN, Bridi AM, Silva CA, Oba A, Medeiros LG, et al. Desempenho e qualidade dos ovos de poedeiras comerciais leves submetidas a dietas contendo torta de nabo forrageiro (Raphanussativus). Ciências Agrárias 2012;33(4):1555-1564.

Rahman M, Koh K. Effects of formic acid-treated shrimp meal on growth performance and nutrient digestibility in broilers. Japan Poultry Science Association 2016;53(3):208-212.

Ramírez-Ramírez JC, Espain Jll, Leyva RG, Ulloa JA, Ulloa PR. Use of biological fish silage in broilers feed: effect on growth performance and meat quality. Journal of Animal \&Plant Sciences 2016;27(3):42934304

Ribeiro PAP, Matos Jr JB, Lara LC, Araújo LF, Albuquerque R, Baião NC. Effect of dietary energy concentration on performance parameters and egg quality of white leghorn laying hens. Brazilian Journal of Poultry Science 2014;16(4):381-388

Rostagno HS, Albino LFT, Donzele JL, Gomes PC, Oliveira RF, Lopes DC, et al. Tabelas brasileiras para aves e suínos:composição de alimentos e exigências nutricionais. Viçosa: Universidade Federal de Viçosa; 2011.

Saleh AA. Effects of fish oil on the production performances, polyunsaturated fatty acids and cholesterol levels of yolk in hens. Emirates Journal Food Agriculture 2013;25(8):605-612.

Sarruge JR, Haag HP. Análises químicas em plantas. Piracicaba: USP-ESALQ: 1974

SAS - Statistical Analysis System. SAS/STAT Software Version 9.2. Cary: SAS Institute; 2008.

Scherr C, Gagliardi ACM, Miname MH, Santos RD. Fatty acid and cholesterol concentrations in usually consumed fish in Brazil. Arquivos Brasileiros de Cardiologia 2014;104(2):152-158.

Silva DJ, Queiroz AC. Análise de alimentos: métodos químicos e biológicos. Viçosa: Universidade Federal de Viçosa; 2012.

Torres RNS, Dreher A. Fontes de lipídeos na dieta de poedeiras: produção e qualidade dos ovos. Revista Eletrônica Nutritime 2015;12(1):39523963.

Valenzuela C, Carvalho F, Morales MS, Reyes P. Efecto del uso de ensilado seco de salmón en dietas de pollos broiler sobre parámetros productivos y calidad sensorial de la carne. Archivos de Medicina Veterinária 2015;47(1):53-59

Wall H, Jönsson L, Johansson L. Effects on egg quality traits of genotype and diets with mussel meal or wheat-distillers dried grains with solubles. Poultry Science 2010;89(4):745-751. 